\title{
Peranan Alat Navigasi Di Kapal Untuk Meningkatkan Keselamatan Pelayaran Di Atas Kapal
}

\author{
Yasin M. Syibli ${ }^{a^{*}}$, Dedi Nuryaman ${ }^{b}$

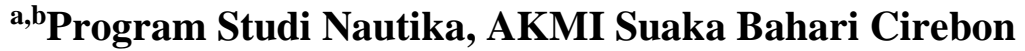 \\ a*Email: yasinsyibli@gmail.com \\ bEmail: dedi.nuryaman@akmicirebon.ac.id
}

\begin{abstract}
ABSTRAK
Aturan jaga yang telah ditetapkan oleh Collision Regulation 1972, STCW 1978 as amended in 2010 Regulation II/1, maka semua kapal wajib melaksanakan tugas jaga tersebut tanpa terkecuali. Adapun dalam pelaksanaannya perwira jaga harus yakin bahwa 1) Semua peringatan dini secara visual yang berlangsung pada situasi yang ada, termasuk kehadiran kapal-kapal dan tanda-tanda dari daratan. 2) Pengamatan yang terus menerus dan baringan dari kapal-kapal yang mendekati. 3) Mengidentifikasi kapal-kapal dan lampu-lampu darat. 4) Mengecek haluan yang dikemudikan dan aba-aba kemudi yang diperintahkan. 5) Pengamatan radar dan echo sounder. 6) Pengamatan perubahan cuaca terutama visibility. Penelitian ini menggunakan jenis pendekatan kualitatif dengan penyampaian secara deskriptif. Tujuan penelitian ini adalah mendeskripsikan peranan alat navigasi dalam meningkatkan tingkat keselamatan pelayaran kapal. Dengan hasil penelitian ini, di mana seorang mualim harus mengoptimalkan dalam pengoperasian dan perawatan alat navigasi guna untuk melaksanakan suatu pengamatan yang layak. Penggunaan alat navigasi seperti binoculars, radar, Automatical Identification System (AIS) dan Electronic Chart Display Information System (ECDIS) sangat membantu untuk mengoptimalkan pengamatan yang ada. Maka meningkatkan keterampilan dalam berdinas jaga terutama dalam hal melakukan pengamatan, harus seoptimal mungkin memanfaatkan bantuan alat navigasi. Karena pengamatan sangat penting guna menghindarkan dari bahaya tubrukan dan mencapai suatu keselamatan dalam pelayaran.
\end{abstract}

Kata Kunci : Alat Navigasi, Keselamatan Pelayaran, Keselamatan Kapal

\begin{abstract}
The guard rules that have been set by Collision Regulation 1972, STCW 1978 as amended in 2010 Regulation II / 1, all ships are obliged to carry out the guard duty without exception. As for the implementation, the duty officer must ensure that 1) All visual early warnings are taking place on the existing situation, including the presence of ships and signs from the land. 2) Continuous observation and bearing of approaching ships. 3) Identifying ships and land lights. 4) Checking the direction of the steering wheel and commanded steering signals. 5) Radar observation and echo sounder. 6) Observation of weather changes, especially visibility. This research uses a qualitative approach with descriptive delivery. The purpose of this study is to describe the role of navigation tools in increasing the level of shipping safety. With the results of this study, where a officer must optimize the operation and maintenance of navigation devices in order to carry out a proper observation. The use of navigation tools such as binoculars, radar, Automatic Identification System (AIS) and Electronic Charts Display and Indentification System (ECDIS) is very helpful in optimizing existing observations. So improving skills in guard duty, especially in terms of making observations, must be as optimal as possible to take advantage of the help of navigation tools. Because observation is very important in order to avoid the danger of collision and achieve a safety in shipping.
\end{abstract}

Keywords: Navigation Tools, Shipping Safety, Ship Safety

https://doi.org/10.46484/db.v2i1.250 


\section{PENDAHULUAN}

Transportasi laut atau pelayaran adalah merupakan media interaksi antar Negara yang berperan sebagai jembatan penghubung yang efektif dan efisien. Kemudian terdapat kurangnya perhatian terhadap keselamatan pelayaran, dapat menghambat penyediaan transportasi di seluruh wilayah maritim. Dan untuk kelancaran pelayaran tersebut baru bisa dicapai apabila persyaratan keselamatan berlayar dan pengetahuan crew kapal khususnya perwira terhadap International Regulation For Preventing Collision At Sea 1972 yang mempengaruhi keselamatan pelayaran dapat dipenuhi.

Sesuai dengan aturan jaga yang telah ditetapkan di atas kapal, semua kapal (Collision Regulation 1972, STCW 1978 as amended in 2010 Regulation II/1) wajib melaksanakan tugas jaga tersebut tanpa terkecuali. Adapun dalam pelaksanaannya perwira jaga harus yakin bahwa 1) Semua peringatan dini secara visual yang berlangsung pada situasi yang ada, termasuk kehadiran kapalkapal dan tanda-tanda dari daratan. 2) Pengamatan yang terus menerus dan baringan dari kapal-kapal yang mendekati. 3) Mengidentifikasi kapalkapal dan lampu-lampu darat. 4) Mengecek haluan yang dikemudikan dan aba-aba kemudi yang diperintahkan. 5) Pengamatan radar dan echo sounder. 6) Pengamatan perubahan cuaca terutama visibility.

Kapal laut sebagai bangunan terapung yang bergerak dengan menggunakan mesin dorong pada kecepatan bervariasi melintas berbagai wilayah pelayaran dalam kurun waktu tertentu akan mengalami berbagai permasalahan yang dapat menimbulkan kecelakaan. Seperti yang diungkapkan Andi Hendrawan (2019: 53-59). Bahwa kecelakaan di atas kapal tidak dapat diprediksi dan dapat terjadi di mana saja dan penyebab terjadinya kecelakaan di atas kapal antara lain karena (1) kesalahan manusia (human eror), (2) kerusakan permesinan kapal, (3) Faktor eksternal dan internal. Gabungan dari seluruh penyebab tersebut pada umumnya terjadi di atas kapal yang mengakibatkan: (1) bertubrukan (collision) dengan kapal lain, (2) kandas (grounding), (3) tenggelam akibat cuaca buruk (bad weather), (4) terbakar (fire), (5) kerusakan mesin (black out/breakdown), dan (6) kapal bersenggolan dengan kapal lain.

Kajian literatur menurut

International Regulation For Preventing Collision At Sea 1972 Pengamatan atau lock out termasuk aturan ke 5 dari aturan internasional di mana setiap kapal harus selalu mengadakan sebuah pengamatan yang layak dengan sebuah penglihatan dan pendengaran atau menggunakan semua peralatan yang tersedia dalam keadaan-keadaan yang ada. Kemudian menurut E.W. Manikome (2008:161) berpendapat bahwa dengan organisasi anjungan, sebuah perusahaan kerja sama dan pembagian tanggung jawab yang ada di antara perwira deck, anjungan, dan pengamatan. Perusahaan mengharapkan semua perwira deck memberikan yang terbaik dalam melaksanakan tugas di anjungan dengan disiplin yang tinggi.

Pengamatan harus selalu dilaksanakan terutama untuk memenuhi aturan 5. Collision Regulation 1972 diambil dari Elsevier (2017:281-291):

1. Senantiasa waspada secara visual maupun pendengaran dan dengan segala cara lain terhadap setiap perubahan situasi.

2. Membuat penilaian tepat terhadap situasi dan resiko tubrukan, kandas, dan bahaya-bahaya navigasi lainnya.

3. Mendeteksi adanya kapal-kapal dan orang di dalam keadaan bahaya, kerangka kapal dan bahaya navigasi lainya.

4. Petugas pengamat harus dapat sepenuhnya melaksanakan tugas tanpa dibebani tugas-tugas lain yang dapat mengganggu pelaksanaan tugas pengamatan.

5. Pemegang kemudi yang sedang bertugas tidak dapat ditugasi sebagai pengamat. Kecuali untuk kapal kecil, 
di mana posisi pengemudi tidak terhalang oleh bangunan kapal.

6. Komposisi tugas jaga menjamin dilaksanakan pengamatan secara terus menerus dan cermat. Nakhoda perlu mempertimbangkan berbagai faktor dalam menyusun komposisi tugas jaga navigasi:

a. Jarak tampak, keadaan laut, dan cuaca

b. Kepadatan lalu lintas dan kegiatan yang sedang dilakukan kapal berlayar.

c. Perhatian yang besar jika berada dekat dengan pemisah (Separation Scheme).

d. Pekerjan yang harus dilakukan di anjungan berkaitan fungsi kapal dan olah gerak.

e. Kebugaran (fitness) masingmasing personil yang ikut tugas jaga.

f. Pengetahuan dan kepercayaan diri secara profesional dari para perwira jaga.

g. Pengalaman perwira, pengenalan alat navigasi, dan prosedur serta kemampuan olah gerak kapal.

h. Semua kegiatan yang dilakukan di kapal pada setiap saat.

i. Status operasional dari alat-alat di anjungan termasuk alat kontrol, dan alarm.

j. Karakteristik olah gerak kapal, termasuk karakteristik balingbaling dan kemudi.

k. Ukuran kapal dan besarnya sudut pandang dari tempat pengamatan.

1. Pengamatan anjungan.

$m$. Prosedur serta petunjuk pelaksanaan jaga yang telah ditetapkan oleh IMO.

Menurut Arfan (2018:14:23)

alat-alat navigasi yang digunakan untuk membantu dalam pengamatan antara lain sebagai berikut :

1. Binoculars atau teropong adalah sepasang teleskop identik atau cermin simetris dipasang side-by-side dan selaras untuk menunjukan secara akurat ke arah yang jaraknya jauh. Dimana manfaatnya adalah: a) Memudahkan perwira jaga melakukan pengamatan

https://doi.org/10.46484/db.v2i1.250 di sekeliling pelayaran kapal. b) Memudahkan mengamati bendabenda kecil seperti bouy-bouy kapal long line yang bisa membahayakan keselamatan pelayaran. c) Memudahkan melihat lampu navigasi sehingga kita bisa mengetahui arah kapal itu. d) Memudahkan mengamati symbol-symbol navigasi, sosok-sosok benda yang berada di sekitar pelayaran.

2. Radar atau Radio Detection and Ranging adalah peralatan navigasi elektronik terpenting dalam pelayaran. Berfungsi mendeteksi dan mengukur jarak di sekeliling kapal. Radar menggunakan pancaran gelombang elektronik. Alat yang akan memancarkan gelombang radio pendek dalam alur sempit (narrow channel) oleh antena berarah (directional antenna). Dan Automatic Radar Plotting Aid (ARPA), di mana kemampuannya dapat membuat trek menggunakan kontak radar. Sistem ini dapat menghitung haluan objek yang dilacak, kecepatan dan titik terdekat atau Closest Plotting Approach (CPA), sehingga tahu jika ada bahaya tubrukan dengan kapal lain atau dengan daratan lainnya. Berikut fungsi biasanya tersedia pada Arpa: (1) Relatif presentasi gerak radar. (2) Membaca informasi seperti kecepatan, jarak, titik terdekat pendekatan Closest Plotting Approach (CPA) dan Time Closest Plotting Approach (TCPA). (3) Kemampuan untuk menampilkan informasi penilaian tubrukan langsung pada layar monitor. (4) Memproses informasi radar jauh lebih cepat daripada radar konvensional namun masih sama pada pembatasan yang sama. Kemudian kegunaan Radar dan Arpa dalam pengamatan adalah untuk meningkatkan taraf menghindari tubrukan di laut mengurangi beban pengamatan dengan memungkinkan mereka secara otomatis mendapatkan informasi sehingga mereka dapat melakukan juga dengan beberapa sasaran karena mereka secara manual merencanakan untuk mengambil tindakan yang tepat apabila akan terjadi bahaya tubrukan. 
3. AIS (Automatic Identification System) atau Sistem pelacakan kapal jarak pendek, digunakan pada kapal dan stasiun pantai untuk mengidentifikasi dan melacak kapal dengan menggunakan pengiriman data elektronik pada kapal lainnya dan stasiun pantai terdekat. Informasi seperti identifikasi posisi, tujuan, dan kecepatan dapat ditampilkan pada layar komputer atau ECDIS (Electronic Charts Display and Indentification System). Sistem AIS terintegrasi dari Radio $V H F$ transceiver standar dengan Loran-C atau GPS (Global Positioning System) dan dengan sensor navigasi elektronik lainnya. Untuk aturannya AIS sendiri, IMO (International Maritime Organization) sudah membuat suatu aturan yaitu Regulation 19 of SOLAS Chapter V yang berisi tentang pemasangan AIS di mana kapal-kapal diwajibkan untuk memasang perangkat $A I S$ transponder terutama pada kapal penumpang, kapal tanker dan kapal berukuran 300 Gross Tonnage ke atas. Peraturan tersebut juga memuat tentang keharusan AIS untuk menyediakan data informasi berupa identitas kapal, jenis kapal, posisi, tujuan, kecepatan, status navigasi dan informasi lainnya yang berhubungan dengan keselamatan pelayaran.

AIS yang digunakan pada peralatan navigasi yang penting untuk menghindari dari kecelakaan akibat tubrukan. Karena keterbatasan dari kemampuan radio, dan karena tidak semua kapal yang dilengkapi dengan $A I S$, sistem ini berarti yang diutamakan untuk digunakan sebagai alat peninjau dan untuk menghindarkan resiko dari tabrakan daripada sebagai sistem pencegah tubrukan secara otomatis, sesuai dengan COLREGS (International Regulations for Preventing Collisions At Sea). Persyaratan AIS hanya untuk menampilkan dasar teks informasi, data yang berlaku dapat diintegrasikan dengan sebuah graphical electronic chart atau sebuah tampilan radar, menyediakan informasi navigasi gabungan pada sebuah tampilan tunggal.

Peranan AIS terhadap pengamatan di alur pelayaran sempit saat perairan dan pelabuhan ramai, VTS (Vessel Traffic Service) boleh ada dalam mengatur lalu lintas kapal. Sekarang AIS menyediakan kesadaran akan lalu lintas tambahan dan menyediakan pelayanan dengan informasi tentang keberadaan kapal lain dan alur lintasannya.

4. ECDIS (Elektronic Chart Display and Information System) adalah alat yang fungsi dan sistemnya dapat memberikan informasi tentang navigasi dan yang kegunaannya adalah untuk memback-up peralatan yang ada, sehingga dapat diterima dan dianggap memenuhi syarat yang ditentukan sesuai aturan V/19 dan V/27 dari konvensi SOLAS 1974 dan amandemennya. Oleh karena itu peralatan ECDIS ini harus memenuhi kriteria standard kinerja dari $I M O$ sesuai bab V Solas 1974. ECDIS juga dirancang seperti menyerupai peta atau bisa disebut juga pemindahan peta ke dalam monitor, dilengkapi dengan infomasi tentang kedalaman laut, tata pemisah lalu lintas, racon-racon, bouy-bouy yang berada di sekitar pelabuhan atau di daerah yang memiliki symbol-symbol navigasi, Sehingga membantu perwira untuk melakukan pengamatan yang lebih optimal. Dan manfaat kegunaan ECDIS terhadap pengamatan 1) Lebih mudah dalam mengetahui keadaan di sekitar pelayaran. 2) Lebih mudah dalam mengetahui indentitas kapal. 3) Dapat memantau terus menerus keadaan di sekitar pelayaran serta lekuk-lekuk kedalaman laut. 4) Lebih jelas dalam mengetahui pergerakan kapal-kapal yang berada di sekitar pelayaran. 5) Memudahkan dalam melayarkan kapal karena tampilan layar menggambarkan kapal dan haluan yang sedang dikemudikan. 6) Terdapat waktu dugaan kedatangan Estimate Time Arrival (ETA) memudahkan mengetahui jarak putar 
kapal ketika anchore karena secara otomatis jarak tersebut diketahui.

5. Echo Sounder adalah perangkat yang menggunakan teknologi sonar untuk mengukur bawah air. Kegunaan dasar Echo Sounder adalah untuk mengukur kedalaman suatu perairan dengan mengirimkan gelombang dari permukaan ke dasar dan ditulis waktunya hingga echo kembali dari dasar.

Kajian literatur atau penelitian yang relevan dengan penelitian ini adalah penelitian yang dilakukan oleh:

1. Andy Triananda dalam skripsinya dan ditulis ulang dalam jurnal ilmiah dengan judul " Anasilis Peran dan Fungsi Navigasi Guna Mendukung Keamanan, Keselamatan dan Kelancaran Pelayaran Berdasarkan Pasal 172 sampai dengan Pasal 177 Undang Undang Nomor 17 Tahun 2008 Tentang Pelayaran" adapun hasilnya adalah: Pemerintah bertanggung jawab untuk membina dan menyelenggarakan pelayaran dalam keadaan terpenuhinya persyaratan keselamatan yang menyangkut angkutan di perairan, kepelabuhan, dan lingkungan maritim tentang keselamatan pelayaran dengan menyelenggarakan Sarana Bantu Navigasi Pelayaran sesuai dengan perkembangan (Triananda, A. (2016)

2. Eni Tri Wahyuni yang berjudul "Peranan Alat Navigasi di Kapal Untuk Meningkatkan Keselamatan Pelayaran di Atas Kapal". Adapun hasilnya adalah: Peran sarana bantu navigasi untuk keselamatan pelayaran dengan adanya perawatan dan pengawasan sarana bantu navigasi dengan baik dan pengadaan sumberdaya manusia yang kompeten dalam penjagaan menara suar sehingga tidak adanya kerusakan dan adanya perawatan terhadap sarana bantu navigasi pelayaran sehingga pemberian informasi tentang bahaya navigasi di alur pelayaran dapat tersampaikan dengan baik dan sarana bantu navigasi pelayaran sekitar dapat membantu navigator dalam

https://doi.org/10.46484/db.v2i1.250 menentukan posisi kapal, melihat bahaya navigasi sehingga dapat menjaga keselamatan pelayaran pada saat memasuki suatu daerah perairan di suatu pulau atau pelabuhan karena mendapat informasi yang jelas tentang bahaya navigasi yang ada di sekitar perairan tersebut. (Erni. 2019: 269 - 274)

\section{METODE}

Penulis dalam penelitian ini menggunakan jenis pendekatan kualitatif dengan penyampaian secara deskriptif. Menurut Margono (2005:8) penelitian deskriptif berusaha memberikan dengan sistematis dan cermat dalam mengungkap fakta-fakta aktual dan dalam populasi memiliki sifat tertentu yang bertujuan untuk mengumpulkan data atau informasi untuk disusun, dijelaskan dan dianalisis. Kemudian Moleong (2007) mengungkapkan dalam metode kualitatif itu adalah sebuah metodologi penelitian yang menekankan pada pemahaman yang mendalam terhadap suatu permasalahan tertentu. Penelitian kualitatif juga merupakan penelitian riset yang bersifat deskripsi. Dan lebih banyak menggunakan analisis serta menekankan pada proses pemaknaan.

Pengumpulan data menggunakan metode observasi, wawancara dan kepustakaan. Seperti Riduwan (2003:51) mengungkapkan bahwa metode pengumpulan data ialah teknik yang digunakan oleh peneliti untuk mengumpulkan data. Pengumpulan data dimaksudkan untuk memperoleh bahanbahan yang relevan, akurat, dan nyata. Untuk memperoleh data-data tersebut, antara lain wawancara, observasi, dan kepustakaan. Di dalam penelitian ini penulis menggunakan beberapa teknik pengumpulan data, antara lain, 1) Wawancara, dimana metode ini merupakan proses tanya jawab secara lisan, dalam hal ini Sugiyono (2010:194) mengungkapkan bahwa teknik wawancara juga digunakan sebagai teknik pengumpulan data apabila peneliti 
akan melaksanakan studi pendahuluan untuk menemukan permasalahan yang harus diteliti, dan juga peneliti ingin mengetahui hal-hal dari responden yang lebih mendalam. 2) Observasi, seperti yang diungkapkan oleh Riduwan (2003:57) bahwa observasi itu kegiatan pengamatan secara langsung ke objek penelitian untuk melihat dari dekat. 3) Kepustakaan atau cara mengumpulkan data melalui peninggalan. Seperti pendapat Sugiyono (2005:83) bahwa kepustakaan merupakan salah satu langkah awal dalam metode pengumpulan data. Metode ini juga merupakan metode pengumpulan yang diarahkan kepada pencarian data dan informasi melalui dokumen-dokumen, baik dokumen tertulis, foto-foto, gambar, maupun dokumen elektronik yang dapat mendukung dalam proses penelitian.

\section{HASIL DAN PEMBAHASAN}

Penulis mendapat banyak pengalaman terutama dalam hal bernavigasi. Dalam hal ini penulis lebih menekankan pembahasan mengenai aturan 5 dalam peraturan pencegahan tabrakan di laut dengan pengamatan. Navigasi adalah suatu teknik untuk menentukan kedudukan dan arah lintasan secara tepat dengan peralatan navigasi. Pada dasarnya terdapat aturanaturan untuk melayarkan kapal salah satunya adalah peraturan pencegahan tubrukan di laut (International Regulation For Preventing Collision At Sea 1972).

Aturan 5 dalam International Regulation For Preventing Collision At Sea 1972 yaitu tentang lock out (pengamatan), setiap kapal harus selalu menyelenggarakan pengamatan yang layak baik dengan penglihatan dan pendengaran maupun dengan semua sarana yang tersedia yang sesuai dengan keadaan dan suasana yang ada untuk membuat penilaian yang lengkap tentang situasi dan bahaya tubrukan. Terdapat kondisi-kondisi khusus yang harus mendapat prioritas untuk dilaksanakannya pengamatan yang lebih intensif.

1. Hal yang harus dilakukan pada saat melakukan pengamatan a) Menjaga kewaspadaan. b) Memperhatikan sepenuhnya situasi dan resiko. c) Mendeteksi kapal-kapal dari navigasi. d) Petugas pengamat harus mampu memberikan perhatian penuh untuk menjamin suatu pengamatan yang baik dan tidak. e) Tugas seorang pengamat dan pemegang kemudi harus terpisah dan tugas pemegang kemudi tidak boleh merangkap atau dianggap merangkap tugas pengamatan, kecuali di kapal-kapal kecil dimana pandangan ke segala arah tidak terhalang dari tempat kemudi dan tidak ada gangguan pandangan pada malam hari.

2. Kondisi-kondisi khusus yang harus mendapat prioritas:

a. Perairan dekat pantai, dan perairan padat lalu lintasnya. Dan penentuan posisi harus sering dilakukan secara berkala.

b. Berlayar di dalam atau dekat bagan pemisah dan di dalam alur pelayaran sempit.

c. Berlayar di daerah tampak terbatas.

d. Berlayar di daerah yang mempunyai banyak bahaya navigasi.

e. Berlayar pada malam hari.

3. Orang yang melakukan pengamatan

Pengoptimalkan tugas jaga navigasi dan melakukan pengamatan dengan baik, maka dari itu setiap crew memerlukan istirahat yang cukup sehingga mengenai jam jaga sudah diatur dalam STCW (Standar Of Training Certification And Wacthkeeping For Seafarer), 2010 pada chapter VIII (delapan). Chapter VIII berisi tentang standar-standar yang berkaitan dengan tugas jaga, diantaranya adalah 1) Pemberian waktu istirahat paling sedikit 10 jam periode 24 jam. 2) Periode istirahat yang salah satu periodenya tidak boleh kurang dari 6 jam. 3) Waktu 
istirahat dapat dikurangi bila terjadi suatu keadaan darurat. 4) Waktu istirahat dapat berturut-turut atau sedikitnya 70 jam dalam 7 hari.

4. Alat-alat yang digunakan untuk pengamatan

Alat-alat navigasi yang biasa di gunakan untuk pengamatan dan saling berhubungan diantaranya:

a. Binoculars atau alat yang gunakan untuk mengamati benda-benda yang letaknya jauh maka dilihat secara visual. Pengamatan keliling dengan menggunakan binoculars dilakukan secara berkala terutama apabila ada terdapat bahaya-bahaya navigasi. Seperti adanya bouy-bouy pancing kapal ikan yang sangat kecil, adanya syombol-syombol navigasi, lampulampu navigasi kapal lain, sosok benda, yang akan membahayakan pelayaran. Maka dari itu perwira jaga bisa mengambil tindakan yang tepat apabila terjadi hal-hal seperti itu.

b. Radar dan ARPA Sesuai dengan perkembangan teknologi dunia maritim, dan dirasa begitu pentingnya radar sebagai alat bantu navigasi beberapa kali IMO (International Maritime Organiszation) membuat resolusi tentang penggunaan Radar di kapal. Mulai dari persyaratan radar, jenis radar, minimal jumlah radar yang harus ada di kapal, pelatihan bagi operator radar sampai dengan sertifikasi bagi operator radar di kapal. Dari ilustrasi tersebut dapat kita ketahui bahwa memang tersedianya radar di kapal merupakan hal yang sangat penting. Serta diatur juga dalam Collision Regulation 1972 aturan 7(b) mengenai penggunaannya. Radar dan Arpa di kapal penulis mengadakan penelitian sudah menjadi satu perangkat sehingga lebih memudahkan dalam pengamatan guna mengetahui kondisi target.

Radar dan Arpa saling berhubungan sehingga harus selalu digunakan dengan tujuan untuk keselamatan navigasi terutama pada saat berlayar di daerah pelayaran ramai, alur pelayaran sempit, pelayaran yang banyak terdapat kapal-kapal ikan long line dan daerah yang jarang dilalui terutama pada malam hari. Menurut pengalaman penulis di kapal MV. OCEAN AMAZING, Radar dan ARPA berperan penting untuk melakukan suatu pengamatan, dikarenakan radar mampu mendekteksi benda-benda yang berada di sekitar pelayaran kapal. Pada saat melakukan pelayaran dari gresik ke pangkal pinang tepat berada di selat bangka yang terdapat kapal ikan jenis long line berada tepat di route pelayaran yang akan dilalui.

Perwira jaga terus mengamati pergerakan kapal ikan tersebut. Terdapat dua kapal ikan yang melintang di haluan yang akan dilewati dengan bouy-bouy nya. Perwira jaga memplotting kapal ikan tersebut. Kapal ikan A mempunyai speed dan bergerak ke Utara dan kapal ikan B tidak mempunyai speed tetapi mempunyai bouy-bouy yang berjajar. Pada saat itu perwira jaga mengambil keputusan untuk memotong kearah buritan kapal karena haluan kapal kita ke Timur dan menembak ke tengah tengah jarak antara bouy dua dan bouy tiga karena jenis bouy tersebut bisa dilewati ke tengah-tengahnya. Perwira jaga mengambil keputusan untuk menghindar jauh dan memotong bouy paling ujung. Dengan ada hal seperti itu maka kapal terpaksa keluar dari route yang telah ditentukan karena untuk menghidar dari bahaya tubrukan dan mencapai keselamatan pelayaran. Adapun bagian-bagian radar yang dipakai perwira jaga untuk membantu pengamatan di kapal MV. OCEAN AMAZING 
adalah:

1) Parallel Index adalah teknik pengamatan jalannya kapal. parallel index merupakan cara yang akan menentukan suatu metode di radar untuk memeriksa kapal selalu berada dalam haluan yang aman yang sudah ditentukan dalam rencana pelayaran. Pararel index ini terdiri dari beberapa garis sejajar tetapi untuk mempermudah pengunaannya biasa hanya dengan mengunakan dua garis sejajar yang searah dengan haluan yang dikemudikan. Garis index akan berada sejajar dengan track di mana kapal akan mengikuti dan dipertahankan untuk melewati jarak aman. Hal ini sering dilakukan mualim I di kapal MV. OCEAN AMAZING pada saat melewati alur pelayaran.

2) VRM (Variable Range Marker) digunakan untuk mengukur jarak suatu target secara lebih teliti, hasil pengukuran jarak dapat dibaca indikator secara digital maupun dialog. Untuk pengamatan VRM ini bisa digunakan sebagai lingkaran jarak aman kapal kita dengan kapal yang lainnya atau apabila kita berlayar di pelayaran yang bahaya piracy VRM ini bisa digunakan sebagai lingkaran aman. Sehingga apabila ada kapal yang mendekat atau sudah memasuki lingkaran tersebut maka otomatis radar atau arpa akan berbunyi alarm.

3) EBL (Electronic Bearing Line) Digunakan untuk membaring suatu target dan bisa dipakai untuk menarik garis batas. Apabila menghadapi keadaan saling memotong $E B L$ bisa digunakan untuk pengamatan kapal lain sehingga tidak terjadinya tubrukan yang terlebih dahulu memploting kapal yang akan memotong haluan, dan memperhatikan pergerakan kapal tersebut dengan melihat Closest Ploting Approach (CPA) dan Time Closest Ploting Approach (TPCA). Di mana CPA untuk mengetahui di mana titik terdekat bertemunya kapal yang dalam keadaan situasi saling memotong. TCPA digunakan untuk mengetahui waktu titik terdekat kapal yang akan memotong tersebut. Apabila CPAnya kurang dari $0,3 \mathrm{~nm}$ maka mempunyai resiko akan terjadinya tubrukan. Sehingga dalam hal ini bisa menggunakan EBL untuk selalu mengamati pergerakan kapal target. Tempatkan EBL di titik yang dianggap aman apabila kapal target dan terus mengamati pergerakan kapal target dengan melihat secara berkala $C P A, T P C A$ dan perbandingan speed kapal target dengan kapal kita. apabila kapal target melewati garis $E B L$ tersebut maka kita bisa beranggapan bahaya tubrukan tidak akan terjadi karena dengan kapal itu melewati garis $E B L$ yang dianggap aman berarti kapal target mempunyai laju yang lebih cepat.

c. AIS (Automatic Identification System) suatu alat untuk mengetahui identitas kapal AIS juga berhubungan dengan Ecdis, Radar dan Arpa kapal yang menggunakan AIS akan terdeteksi di AIS. Menghadapi situasi berhadapan, maka peranan AIS diperlukan untuk mengetahui keadaan kapal lain. Perwira jaga harus mengamati pergerakan kapal tersebut, dan sesuai aturan P2TL apabila keadaan saling berhadapan masingmasing kapal harus mengubah haluannya ke kanan atau ketemu di lambung kiri. Akan tetapi apabila kapal dari salah satu yang akan berhadapan dalam keadaan olah geraknya terbatas, maka aturan itu bisa dilanggar. Kemudian AIS juga berfungsi sebagai pemberitahu identitas kapal kita ke kapal yang lain.

d. ECDIS (Elektronic Chart Display and Information System) adalah untuk memudahkan mengetahui keadaan pelayaran di sekitar kapal terutama tentang keadaan laut, keadaan tata pemisah lalu lintas apabila melewati alur pelayaran atau VTS (Vessel Traffic System). ECDIS (Elektronic Chart Display and Information System) menampilkan route pelayaran yang akan dilalui dengan jelas menggambarkan sebuah 
kapal dengan berjalan di dalam suatu route pelayaran. Sehingga apabila terdapat kapal-kapal di sekitar haluan atau route yang akan kita lewati, ditampilan layar ECDIS (Elektronic Chart Display and Information System) akan terlihat jelas maka dari itu hal ini bisa lebih memudahkan dalam pengamatan dan bisa memudahkan dalam hal untuk mengambil tindakan yang tepat untuk menghindari bahaya tubrukan.

e. Alat atau perangkat yang menggunakan sistem teknologi sonar untuk mengukur kedalaman suatu perairan dengan mengirimkan gelombang dari permukaan ke dasar atau disebut Echo Sounder dan Radar. Tetapi pada keseluruhan alat navigasi di kapal MV. OCEAN AMAZING dalam kondisi baik terkecuali 1 radar dan echo sounder, dengan tingkat kerusakan yang berbeda, seperti :

1) Terdapat 2 buah radar pada kapal, tetapi yang dapat berfungsi dengan baik hanya satu, sedangkan radar yang lainnya dalam kondisi rusak. Hal yang kami lakukan adalah mengirim Berita Acara berupa kerukan alat navigasi yaitu radar. Akan tetapi belum ada respon atau tanggapan dari pihak kantor tentang radar rusak tersebut. Karena hal tersebutlah kami melakukan perawatan dan penggunaan radar yang berfungsi dengan baik dengan hanya menghidupkan radar pada saat kondisi tertentu. seperti kondisi berkabut, dalam hujan deras, dan pada saat malam hari.

2) Pada kapal tersebut hanya terdapat satu echosounder, tetapi sudah tidak berfungsi dengan baik. Berita acara sudah kami kirimkan untuk meminta penggantian atau perbaikan pada Echosounder, tetapi sama seperti berita acara yang kami kirimkan pada radar, pihak kantor belum ada respon atau tanggapan mengenai hal ini. Sedangkan tindakan kami agar tetap dapat berlayar dengan tidak menggunakan echo sounder yaitu dengan cara melihat kedalaman laut dengan berpatokan ke peta.

\section{SIMPULAN}

Berdasarkan hasil penelitian, seorang mualim harus mengoptimalkan dalam pengoperasian dan perawatan alat navigasi guna untuk melaksanakan suatu pengamatan yang layak. Penggunaan alat navigasi seperti binoculars, radar, Automatical Identification System (AIS) dan Electronic Chart Display Information System (ECDIS) sangat membantu untuk mengoptimalkan pengamatan yang ada. Penggunaan bagian-bagian radar juga sangat berperan dalam pengoperasian radar terhadap pengamatan seperti: parallel index, Electronic Bearing Line (EBL), Variable Range Marker (VRM). Menggunakan seoptimal mungkin kinerja bagian-bagian radar tersebut. Kemudian cara mendapatkan suatu indentitas suatu kapal yaitu menggunakan Automatic Identification System (AIS). Alat tersebut membantu untuk mendapatkan informasi suatu kapal apabila kapal tersebut membahayakan pelayaran tetapi alat ini hanya bisa mendeteksi suatu informasi apabila kapal target mempunyai AIS. Selain dari peranan ECDIS terhadap pengamatan untuk lebih memudahkan mengamati keadaan laut yang akan dilayari sehingga kapal bisa lebih mudah bergerak apabila ada bahaya navigasi. Maka dari itu untuk meningkatkan keterampilan dalam berdinas jaga terutama dalam hal melakukan pengamatan, harus seoptimal mungkin memanfaatkan bantu alat navigasi. Karena pengamatan sangat penting guna menghindarkan dari bahaya tubrukan dan mencapai suatu keselamatan dalam pelayaran.

\section{DAFTAR PUSTAKA}

Arfan, D. (2018). Peningkatan kemampuan perwira jaga fresh graduate dalam menggunakan alat-alat navigasi untuk mencegah bahaya tubrukan di mv. Energy midas (Doctoral dissertation, 


\begin{tabular}{l} 
POLITEKNIK ILMU \\
PELAYARAN SEMARANG). \\
http://repository.pip- \\
semarang.ac.id/587/6/13\%20- \\
\hline \%20BAB\%202\%20\%2810- \\
30\%29.pdf
\end{tabular}

Hendrawan, A. (2019). Analisa Indikator Keselamatan Pelayaran pada Kapal Niaga. Saintara: Jurnal Ilmiah Ilmu-Ilmu Maritim, 3(2), 53-59.

STCW 1978 as amended in 1995 Regulation II/1

Konvensi SOLAS 1974 tentang Keselamatan Penumpang dan Awak Kapal di Laut

Margono, S. (2005). Metodologi Penelitian Pendidikan. PT. Rineka Cipta.

Moleong, Lexy J. (2007). Metodologi Penelitian Kualitatif. PT. Remaja Rosdakarya.

Riduwan. (2003). Dasar-Dasar Statistik. Alfabeta

STCW (Standar of Training Certification and Wachkeeping For Seaferer) (2010). Pada Chapter VIII. Berkaitan dengan Tugas Jaga.

Sugiyono. (2010). Metode Penelitian Pendidikan Pendekatan Kuantitatif, Kualitatif, dan $R \& D$. Alfabeta

Sugiyono. (2005). Metode Penelitian Kuantitatif Kualitatif dan $R \& D$. Alfabeta

Triananda, A. (2016) Analisis Peran Dan Fungsi Navigasi Guna Mendukung Keamanan, Keselamatan Dan Kelancaran Pelayaran Berdasarkan Pasal 172 Sampai Dengan Pasal 177 Undang. Jurnal Hukum Prodi Ilmu Hukum Fakultas Hukum Untan (Sekripsi S1 Fakultas Hukum Universitas Tanjungpura).

Wahyuni, Eni Tri. (2019). Peranan Alat Navigasi Di Kapal Untuk Meningkatkan Keselamatan Pelayaran Di Atas Kapal. Proceeding of 1st National Seminar on interdesciplinary Studies. Politeknik Bumi Akpelni:
Semarang. Published 2019-08-13. p. 269 - 274. $\underline{\text { https://e- }}$ journal.akpelni.ac.id/index.php/pr osiding/article/view/92 